\title{
The Determinants of Microfinance Profitability: Evidences From Sri Lankan Microfinance Institutions
}

\author{
D. M. N. S. W. DISSANAYAKE \\ Assistant Lecturer, Faculty of Commerce and Management Studies \\ Department of Commerce and Financial Management, University of Kelaniya \\ neelacksha911@gmail.com
}

\begin{abstract}
This study was undertaken with the objective of asserting the significant determinants of microfinance profitability in Sri Lankan microfinance institutions. This study is based on eleven microfinance institutions in Sri Lanka, within the period of 2005 2010, which are practicing microfinance at present. In this study, profitability is measured by profitability and sustainability ratios. Determinants of microfinance profitability are measured by efficiency and productivity, financing structure and portfolio quality ratios. Profitability is measured by return on equity ratio, return on assets ratio, and profit margin ratio. Sustainability is measured by operational self sufficiency ratio. Efficiency and productivity are measured by operating expense ratio, personal productivity ratio and cost per borrower ratio. Financing structure is measured by debt/equity ratio. Portfolio quality is measured by writeoff ratio. Finally, the researcher intends to postulate that, the cost per borrower is a determinant for return on equity and operational self sufficiency. Besides, the operating expense ratio and write off ratios are determinants of return on equity, return on assets and profit margin. Observations of the debt/equity variable of the study imply causality for the return on assets and operational self sufficiency as a determinant of respective models.
\end{abstract}

Key words: Efficiency, Microfinance, Productivity, Profitability, Sustainability.

\section{Introduction}

Sri Lanka is well known for its significant improvements in human development indicators. Though it is the fact, Sri Lanka remains a low income country (Kelegama, 2001). The poor entail financial services particularly savings and credit services as much as the rich, or even more (Alwis, 2008). Though finance is a prerequisite for the poor, inability to access formal finance has become a 
critical concern in this regard (Safiuddin, 2011). Besides, there is a perception that formal financial institutions often do not meet financial needs of the poor (Alwis, 2008). Under these circumstances, the poor often tend to resort to alternative savings methodologies such as accumulating excess funds at home and/ or saving in kind; i.e. accumulated gold, livestock and consumer durables (Alwis, 2008). Obviously, borrowing from the informal sector is comparatively more risky. At present, around $18.3 \%$ of households do borrow from the informal sector (GTZ ProMis, 2009).

Starting with the Grameen Bank founded by professor Mohammd Yunus in the 1970s, microfinance is considered as a viable tool to alleviate poverty while serving to the poorest people on the globe (Ugur, 2006). In Sri Lanka, microfinance is fueled by many institutions' interests, such as Regional Development Banks (RDBs) and other Licensed Specialized Banks, Co-operative Rural Banks and other co-operatives, Thrift and Credit Co-operative Societies (TCCSs), Samurdhi Bank Societies (SBSs), NGOs (Non-governmental Organizations)-MFIs (Microfinance Institutions), and other financial institutions including commercial banks, registered financial companies, etc. ${ }^{1}$

Based on the regulatory and accountability aspects, it is assumed, that, microfinance sector in Sri Lanka is more productive, if MFls operate in a lucrative manner in alleviating poverty. So, MFls must be well designed to be profitable and to accomplish a moral obligation in alleviating poverty through implementing effective microfinance programs. Eventually, a win-win scenario will also be attained for both parties (Ugur, 2006).

Predominantly, this paper attempts to identify significant determinants of profitability in of microfinance institutions in Sri Lanka. Eleven microfinance institutions have been selected within the period of 2005-2010. Multiple regressions have used to determine the significant predictor variables microfinance profitability.

This paper is structured with number of sections starting from an introduction which illustrates the notion of microfinance and the significance of this study in Sri Lankan context. Secondly a detailed literature reviews illustrating the

Microfinance industry report, Sri Lanka, 2009, PP. 14 
prerequisites and the desired variables of the study is included. The third section is devoted to discuss the methodology and that depicts the techniques used to assert the significant determinants of microfinance profitability and the operationalization of variables. Fourthly the analysis and discussion of findings are presented with an assessment of quality of data. The fifth section deals with the discussion of findings of the study.

\section{Review of literature}

Asian Development Bank (2000) defines; microfinance is the provision of a broad range of financial services such as deposits, loans, payment services, money transfers, and insurance to poor and low-income households and, their microenterprises.

Poverty in Sri Lanka has declined from $15.2 \%$ in 2006/07 to $8.9 \%$ in 2009/ 10 (DCS, 2011) and that accounts for $41 \%$ reduction. Though these are the facts relates to poverty context in Sri Lanka, (Sanderatne, 2003) defined the prerequisite of microfinance initiatives to Sri Lanka. He asserted that, while poor communities served by MFIs have benefited in terms of improved income, increased employment and empowerment, the impacts have not been on a scale that is likely to lead to a transformation of either the economy or society. MFIs have alleviated poverty, not eradicated it, even in small communities.

\section{Return on Equity}

Basically the Return on Equity (RoE), measures the profitability of the institution and indicates how well the firm has used the resources of owners. The earning of a satisfactory return is the most desirable objective of a business. This ratio reflects the extent to which this objective has been accomplished.

The return on equity is an inevitable measure of profitability, (Ugur, 2006). Finally supporting evidence to (Ugur, 2006), can be found in (Kereta, 2007) studies. Stating, MFIs are operational sustainable measured by return on equity and the industry's profit performance is improving over time. Meanwhile, (Tucker and Miles, 2004), declared stating, there is a possibility that self sufficient MFIs with positive return on equity may be attaining those results by reducing levels of services to the poorest of the poor, those with the greater needs. 


\section{Profit Margin}

Small deposits entail high administrative costs that will turn them into an unprofitable business for MFIs, (Schmidt and Zeitinger, 1996). The underlying theme is that a focus on efficiency will help institutions reach more clients and attain higher levels of profitability, (Gerschick , 2000).

Sanderatne, (2003), addressed some repercussions of losses that may incur resulting inadequate income to cover costs of operations, cost of finance, and the provision for bad debts, would be eroding its capital base, unless there is a continuous flow of funds outside to offset the erosion of capital. Moreover, the rising profitability of the Leaders is driven by their ability to take advantage of economies of scale, as they are able to better leverage their initial investments. These MFIs are also successfully supplementing their interest income with fee based revenue through insurance, managing portfolios, and other product sales, (Parameshwar," Aggarwal,, Zanchi, \& Shankar, 2010). Meanwhile, the microfinance profitability reflects how microfinance institutions run the given environment in which they operate, which should epitomize efficiency, risk management capabilities, their competitive strategies, quality of their management and levels of capitalization, (Muriu, 2011).

Tucker and Miles, (2004), asserted the fact that Asian MFIs usually corresponds with negative profit margins. And they postulated, the allocation of scare capital by NGOs to the most successful MFIs should be a priority, but allocation cannot be solely based on profitability of recipient institution.

\section{Return on Assets}

A narrow insistence on cost recovery and the elimination of subsidies would only force MFIs to shed the poorest from their portfolios of borrowers because they are precisely the most difficult and costly to attend, (Hulme \& Mosley, 1996). Their findings are indirectly relates with the return on assets. As return on asset ratio is calculated excluding grants or donations from the net income that is being taken into consideration.

Indicators that are employing to evaluate organizational efficiency and profitability of MFIs, such as return on assets do not show the whole picture, (Gerschick, 2000). They kept on emphasizing the fact that sustainability is not 
a sufficient measure of financial performance. Meanwhile, regulators should not penalize MFIs for higher operational costs if they can demonstrate reasonable average return on assets, (Charitonenko \& Silva, 2002).

Ugur, (2006), developed an intuitive argument based on the notion of micro banks are the best institution in engage with microfinance. Eventually, he kept on stressing that, individual based lending 'draws on traditional banking practices and involves a standard bilateral relationship between bank and customer'. This method appears as the most vulnerable one to weak enforcement policies and information asymmetries. Only for this type of lending the authors observe a positive return on assets.

Moreover opposing scenario occurs between (Gerschick, 2000) findings and (Ugur, 2006), findings on return on assets. Ugur, (2006) kept on stating that return on assets is a definite metric of profitability whereas, Gerschick, (2000) emphasized the opposite of this.

Eventually, Ugur, (2006) concluded stressing micro banks which are corresponds with the highest assets are exhibiting a positive outlook in terms of the growth of their revenue and their assets. Consequently their deposits have also increased continually throughout the years suggesting that they were able to serve an increasing number of clients. Statements of Ugur, (2006) suggesting that return on assets and profitability are positively correlated.

Kereta, (2007), emphasized in his findings from financial sustainability angle, it finds that MFIs are operational sustainable measured by return on asset and return on equity and the industry's profit performance is improving over time. This is once more confirming the statements of Ugur, (2006) which stated on profitability and return on assets.

Another supporting judgment for (Ugur, 2006 and Kereta, 2007), can be stated with reference to (Muriu, 2011 ) studies. It further defines that, return on assets remains a valuable measure of MFI's profitability. Additionally, the Microfinance Financial Reporting Standards (MFRS) recommends the use of return on assets as measures of MFI profitability rather than operational self sufficiency. 


\section{Operational Self sufficiency}

The productivity of a MFI is not ensuring the self sustainability. Further to increase productivity, it may important to reduce per unit costs and improve self sufficiency, (Nagarajan, 2000). Besides, there are at least four direct drivers that MFIs can use as levers to increase productivity: client retention, staff retention, staff remuneration, and staff training.

Nevertheless, self sufficiency and administrations costs are negatively correlated. Meanwhile, productivity and self sufficiency are positively correlated. Significant fact is that the self sufficiency will peak at a 30 percent maximum with the positive correlation and increase at a diminishing rate thereafter, (Nagarajan, 2000). In fact, the sustainability can be defined as a program's capacity to remain financially viable in the absence of domestic subsidies or foreign support (Woolcock, 1999). Conversely, (Tucker and Miles, 2004), affirmed that, sustainability includes generating sufficient profit to cover expenses while eliminating all subsidies.

Without sustainability, MFI are not a going concern, making the goal of poverty alleviation unreachable, (Rhyne, Elisabeth, and Otero, 1999). Besides, (Christen and McDonald, 1998), defined in the micro banking bulletin highlights; administrative expense ratio is a significant determinant of financial self sufficiency. Two kind of sustainability can observe in assessing MFIs performances. They are operational self sustainability and financial self sustainability, (Meyer, 2002). Further he asserted, operational self sufficiency is when operating income is sufficient enough to cover operational costs like salaries, suppliers, loan losses, and other administrative costs. Besides, to attain financial viability, self sufficiency is required (Sanderatne, 2003).

Tucker and Miles, (2004) stated that, the paradox of sustainable microfinance institutions requires the tradeoff between lending to poverty alleviation and attaining self sufficiency. They confirmed that, the balance is difficult to attain, but financially sustainable MFI will be able to increase borrowing in private capital markets. Conversely the statement is confirmed by Rhyne, et al, 1999). (Woller, Gary, Dunford, Christopher and Woodworth, 1999), addressed strategies to attain self sufficiency for an institution. There are, drive down 
administration and per unit output costs, drive up staff productivity, achieve significant scale, and charge appropriate interest rates.

\section{Operating Expense}

This indication gives an overall measure of efficiency of a lending institution. For this reason the OER often referred to as the efficiency ratio. Mainly, the OER measures the institutional cost of delivering loan services (Stauffenberg, Jansson, Kenyon, Cruz \& Badiola, 2003).

To reduce costs, delegation of costs can be diminished via diversification, (Diamond, 1984). Moreover, economic incentive schemes to staff productivity are significant to enhance operational efficiency, (Elser, Hannig and Winsiwski, 1999). The underlying theme is that a focus on efficiency will help institutions to reach more clients and attain higher levels of profitability, (Gerschick, 2000).

A study on determinants of financial viability, (Sanderatne, 2003) defined that the operational efficiency and low administration costs have an important bearing. Besides, a study on financial performances, (Tucker and Miles, 2004), declared that, many MFIs are not considered sustainable. By stating the fact, (Tucker and Miles, 2004), confirmed that the operational efficiency is inevitable to attract funds.

The relative smaller size and shorter maturity of loans drives transaction costs higher for MFIs, (Donohoe, Mariz, Littlefield, Reille \& Kneiding, 2009). Further they asserted higher costs (especially operating costs) justify higher rates. Reduction in operating expense ratio is primarily driven by reductions in nonpersonnel expenses, (Parameshwar, et al, 2010).

The operating expense ratio is an indicator of institutional effectiveness, (Woller, et al, 1999), (Stauffenberg, et al, 2003). Added to this, (Woller, et al, 1999) asserted that, an increase in the administrative expense ratio ${ }^{2}$ is hypnotized to be associated with a decrease in financial self sufficiency and vice versa.

2 Administrative Expense Ratio is more or less synonymous to operating expense ratio 


\section{Personal Productivity}

Productivity is the amount of quality services delivered by microfinance staff to their clients and it quantifies the employees' efforts to deliver a MFls output. By increasing productivity, a MFI can lower per unit costs, improve efficiency, and ultimately enhance self sufficiency, (Nagarajan, 2000). In fact, staff productivity is the primary indicator to measure the productivity, (Nagarajan, 2000). A MFI's entire staff is a relevant unit of serve production, so the best measure of productivity collectively accounts for the efforts of front and back offices. Eventually she emphasized that, the staff productivity indicator is therefore more useful when comparing between less similar MFIs.

Incentive based systems are vital to enhance staff productivity, (Barrès, 2001). To enhance efficiency, increasing staff productivity through incentive systems, transportation equipment, and establishing specialized staff positions for routine administrative functions are vital, (Gerschick, 2000). One key to achieving profitability is investing more heavily in staff costs, (Morduch, et al, 2006).

(Woller, et al, 1999), asserted that the staff productivity ${ }^{3}$ ratio measures the total number of staff required to produce a given level of output, as measured by borrowers. Eventually, the staff productivity is hypothesized to be positively associated with self sufficiency.

\section{Cost per Borrower}

(Espallier, Bert D., Isabelle Guérin, and Roy Mersland, 2009) and (Hermes, et al, 2008), ideas on woman borrowers and the impact it has on the profitability are same. Woller, et al, (1999), identified that the cost per borrower ratio measures the value of total monetary and in kind inputs required to produce a given level of output, as measures by borrowers. He further defined that the cost per borrower is hypothesized to be inversely associated with financial self sufficiency.

\section{Write offs}

(Parameshwar, et al, 2010), in MBB, states the factors contributing to the increase in loan sizes are: Graduation of clients in mature markets to higher loan sizes,

3 Staff Productivity ratio is synonymous to personal productivity ratio 
increased focus of MFIs on urban clients with higher credit needs than rural clients, introduction of individual lending and increased ticket size for the first loan to new customers by some MFIs. Here the loan size has taken into consideration as loan size is an inevitable determinant of gross loan portfolio.

\section{Debt / Equity (Leverage)}

Rhyne et al, (1992) stated that institution which have high capital structure with equity, is tend to be more profitable. The financial viability does not mean that a MFI depends on its own funds, (Sanderatne, N. 2003). High leverage is related to higher profit efficiency (Berger, Allen, and Patti, 2002), while, (Maisch, Felipe, Sori, and Westley, 2006) identified that, it is important for an MFI to create a capitalization plan before beginning to look for new shareholders. The creation of this capitalization plan is step one in the process of issuing debt or equity.

Ugur, (2006), portrays this new approach to microfinance by managing debt funds and attracting commercial investors to the microfinance industry. Moreover, (Donohoe et al, 2009) studied, the leverage of mature MFIs is only slightly lower than that of traditional banks.

Microfinance institutions that employ higher debt in their capital structure are more profitable, and highly leveraged microfinance institutions are more profitable, (Muriu, 2011). Besides, a higher debt ratio can enhance the rate of return on equity capital during good economic times, (Muriu, 2011 ). Moreover, it also appears that NGO type of microfinance institutions rely more on debt financing relative to other type of microfinance institutions, perhaps because many are not regulated to mobilize deposits.

\section{Methodology}

Mainly, the researcher intends to analyze the data by means of employing multiple regression models. The $T$ test implies the significant variables determining return on equity in MFIs. Finally, the researcher evaluated the quality of data by means of multicollinearity, autocorrelation, normality and heteroscedasticity, by employing tolerance, Durbin-Watson, Normal probability plots of the standardized residual plots for four assumptions respectively. 


\section{Data and Sample}

The MFIs were selected based on the availability of data for a period of 6 years (2005-2010). Therefore, the sample consists of 66 observations consist of eleven micro finance institutions in Sri Lanka. The data were provided by the "Mix Market" web site which is known as the Microfinance Information Exchange $(\mathrm{MIX})^{4}$.

\section{The Variables}

The study investigates the significant determinants of microfinance profitability in Sri Lankan MFIs. To measure the determinants of microfinance profitability, five measures are used as independent variables which were extracted from Stauffenberg, et al, (2003) studies $^{5}$. Namely, Operating Expense Ratio (OER), Personal Productivity Ratio (PPR), Write-off Ratio (WoR), Cost per Borrower Ratio (CpBR), and Debt/Equity Ratio (DER). Moreover, to determine the variables to measure profit generated, four measures are used as dependent variables. Namely, Return on Equity Ratio (RoER) (Stauffenberg et al, 2003), Return on Asset Ratio (RoAR) (Stauffenberg et al, 2003 and Pandey, 1999), Operational Self-Sufficiency Ratio ${ }^{6}$ (OSSR) (TheMix, 2007) and Profit Margin Ratio (PMR) (TheMix, 2007).

\section{Theoretical Models}

Model I $\quad \operatorname{RoER}=\alpha+\beta_{1}(\mathrm{OER})+\beta_{2}(\mathrm{PPR})+\beta_{3}(\mathrm{WoR})+\beta_{4}(\mathrm{CpBR})+\beta_{4}(\mathrm{DER})+\mathrm{e}$

Model II $\quad \operatorname{RoAR}=\alpha+\beta_{1}(\mathrm{OER})+\beta_{2}(\mathrm{PPR})+\beta_{3}(\mathrm{WoR})+\beta_{4}(\mathrm{CpBR})+\beta_{4}(\mathrm{DER})+\mathrm{e}$

Model III $\quad$ OSSR $=\alpha+\beta_{1}(\mathrm{OER})+\beta_{2}(\mathrm{PPR})+\beta_{3}(\mathrm{WoR})+\beta_{4}(\mathrm{CpBR})+\beta_{4}(\mathrm{DER})+\mathrm{e}$

Model IV $\quad$ PMR $=\alpha+\beta_{1}(\mathrm{OER})+\beta_{2}(\mathrm{PPR})+\beta_{3}(\mathrm{WoR})+\beta_{4}(\mathrm{CpBR})+\beta_{4}(\mathrm{DER})+\mathrm{e}$

\footnotetext{
4 Data from the MIX market are reliable and it has been used by many researchers who are interest in the microfinance field. Further, the MIX market review data of MFIs for coherence and consistency, and reclassify according to international financial reporting norms.

5 Damian, v, S., Tor, J., Naomi, K., María, C, B, B., "Performance indicators for microfinance institutions", Technical guide, 3rd edition, July 2003.

- CGAP, Financial analysis for microfinance institutions,2009
} 


\section{Analysis and Discussion of Findings}

\section{Quality of Data}

Quality of data of study has asserted with evaluating collinearity, serial correlation (autocorrelation) normality and heteroscedastisity analysis. Since tolerance levels of the study lie above 0.50 , the researcher affirmed that the models do not corresponds with, no multicollinearity. Simply stated, all variables of the study are act independently. The notion of serial correlation was evaluated considering Durbin-Watson values. Further, models were corresponded with Durbin-Watson values which are closer to 2 . Thus the researcher affirmed that the models of the study do not correspond with serial correlation. Figure 01 below illustrates normality and heteroscedastisity assumptions. The researcher satisfied with the normality assumption since the normal probability plots are not too far from the straight line of each plot. The assumption of heteroscedastisity was not violated since the figures are fluctuating randomly around zero in an un-patterned fashion.

Figure 1: Normality and heteroscedasticity analysis of the models of the study
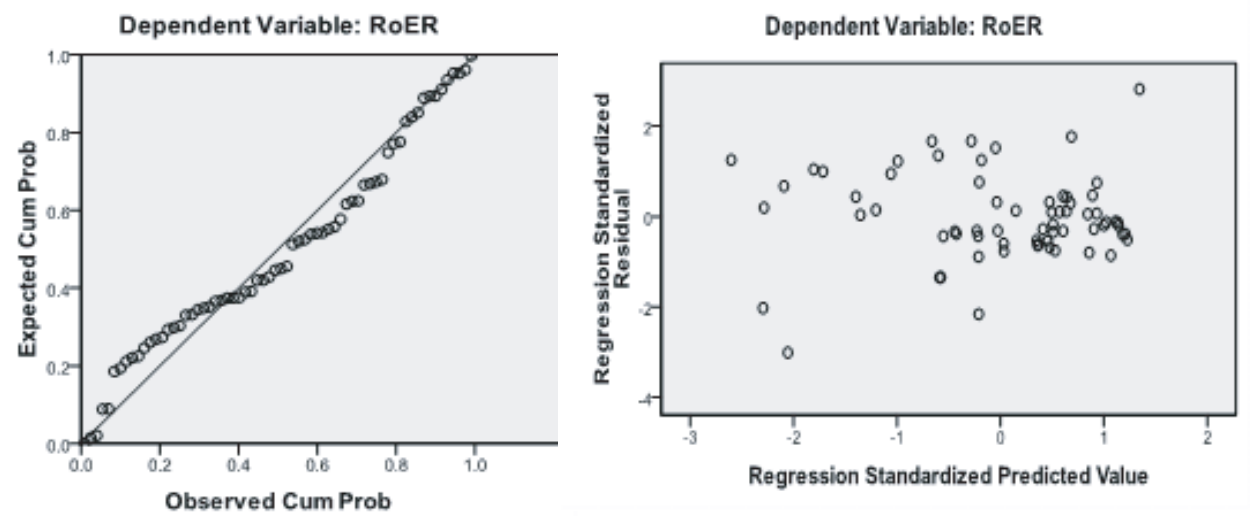
The Determinants of Microfinance Profitability: Evidences From Sri Lankan Microfinance Institutions

Dependent Variable: RoAR

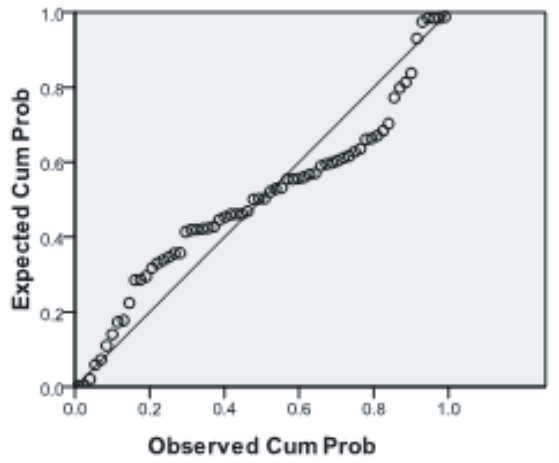

Dependent Variable: OSSR

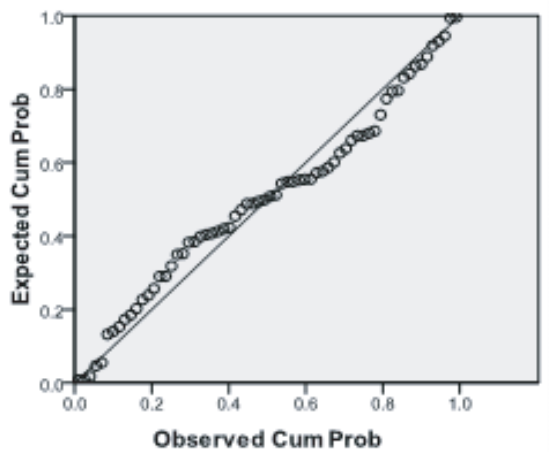

Dependent Variable: PMR

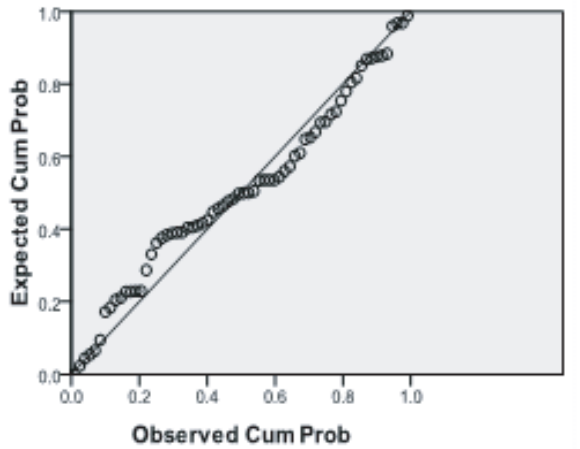

Dependent Variable: RoAR

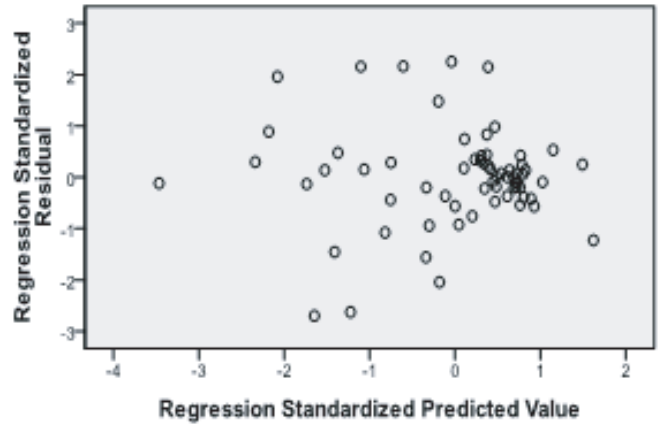

Dependent Variable: OSSR
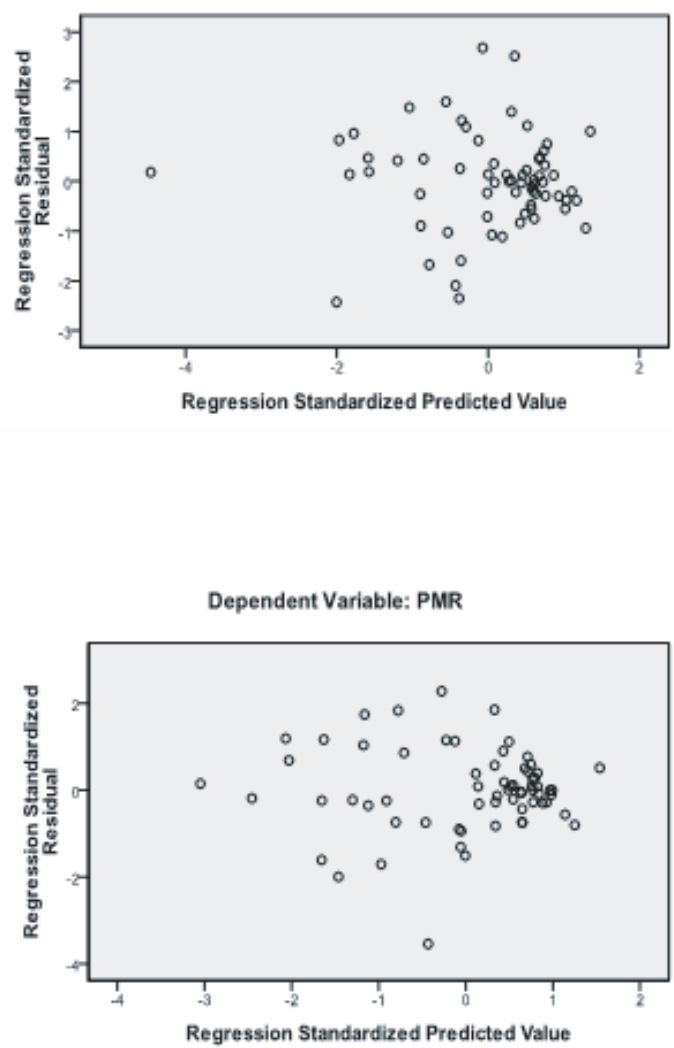

Source: Research data 


\section{Empirical Results}

\section{Determinants of Profitability}

Table 1: Results of multiple regression analysis over different determinants of profitability

\begin{tabular}{|c|c|c|c|c|}
\hline Variables & $\begin{array}{l}\text { Return on Equity } \\
\text { (Model I) }\end{array}$ & $\begin{array}{l}\text { Return on Assets } \\
\text { (Model II) }\end{array}$ & $\begin{array}{l}\text { Operational } \\
\text { Self Sufficiency } \\
\text { (Model III) }\end{array}$ & $\begin{array}{l}\text { Profit Margin } \\
\text { (Model IV) }\end{array}$ \\
\hline Intercept & 12.741 & 5.276 & 135.707 & 27.136 \\
\hline $\begin{array}{l}\text { Operating } \\
\text { expenses }\end{array}$ & $\begin{array}{c}(\beta-1.821) \\
(\text { t. }-5.198) \\
(\text { Sig } 0.000) *\end{array}$ & $\begin{array}{c}(\beta-0.351) \\
(t .-4.328) \\
(\text { Sig } 0.000) * \\
\end{array}$ & $\begin{array}{r}(\beta-1.240) \\
(t .-1.937) \\
(\text { Sig. } 0.057) \\
\end{array}$ & $\begin{array}{c}(\beta-1.767) \\
\text { t. }-3.899) \\
(\text { Sig. } 0.000) * \\
\end{array}$ \\
\hline $\begin{array}{l}\text { Personnel } \\
\text { Productivity }\end{array}$ & $\begin{array}{c}(\beta-1.821) \\
(t .1 .574) \\
(\text { Sig } 0.121)\end{array}$ & $\begin{array}{c}(\beta-0.351) \\
(+-0.976) \\
(\operatorname{Sig} 0.333) \\
\end{array}$ & $\begin{array}{c}(\beta-1.240) \\
(\text { t. }-0.088) \\
(\text { Sig } 0.930)\end{array}$ & $\begin{array}{r}(\beta-1.767) \\
(+0.037) \\
(S i g 0.971) \\
\end{array}$ \\
\hline Write off & $\begin{array}{c}(\beta 3.806) \\
(\mathrm{t} .2 .684) \\
(\mathrm{Sig} 0.009)\end{array}$ & $\begin{array}{c}(\beta 0.638) \\
\left(\begin{array}{ll}\dagger & 0.945) \\
(\operatorname{Sig} & 0.056)\end{array}\right)\end{array}$ & $\begin{array}{c}(\beta 3.132) \\
(\text { t. } 1.209) \\
\text { (Sig. 0.232) } \\
\end{array}$ & $\begin{array}{c}(\beta 4.091) \\
(\dagger 2.229) \\
\text { (Sig. 0.030)* }\end{array}$ \\
\hline Cost per Borrower & $\begin{array}{c}(\beta 0.004) \\
(t .2 .660) \\
(S i g 0.010) *\end{array}$ & $\begin{array}{c}(\beta 0.000) \\
(t .-1.851) \\
(\text { Sig } 0.069) * \\
\end{array}$ & $\begin{array}{c}(\beta-0.005) \\
(t .-2.164) \\
(\text { Sig. } 0.034)\end{array}$ & $\begin{array}{c}(\beta 0.000) \\
\text { t. }-0.402) \\
\text { (Sig. } 0.689) *\end{array}$ \\
\hline Debt/Equity & $\begin{array}{r}(\beta-0.116) \\
(t .-0.636) \\
(\operatorname{Sig} 0.527) \\
\end{array}$ & $\begin{array}{c}(\beta 0.096) \\
(+2.285) \\
(\text { Sig } 0.026) * \\
\end{array}$ & $\begin{array}{c}(\beta 0.818) \\
(\text { t. } 2.459) \\
\text { (Sig. 0.017) * }\end{array}$ & $\begin{array}{c}(\beta 0.424) \\
(\dagger 1.801) \\
(\text { Sig. 0.077) } \\
\end{array}$ \\
\hline $\mathrm{R}^{2}$ & 0.421 & 0.534 & 0.416 & 0.428 \\
\hline $\mathrm{F}$ & 8.737 & 13.761 & 8.552 & 8.996 \\
\hline Obs & 66 & 66 & 66 & 66 \\
\hline
\end{tabular}

Source: Research Data

*. Significant at the 0.05 level (2-tailed)

$\mathrm{R}^{2}$ value of the study implies that $42.1 \%, 53.4 \%, 41.6 \%$ and $42.8 \%$ of fitness can be observed in the sample regression lines for all four models respectively. Reasonably good fit among variables can be seen implying an average value of $45 \%$.

\section{Significant Determinants of Microfinance Profitability}

According to table 1, annotations of the operating expense ratio imply that the variable is a determinant of return on equity, return on assets and profit margin. Further, neither models of the study implies the personnel productivity 
is a statistically significant predictor variable. Suggesting personal productivity is not a determinant of profitability. Besides, It can be stated that the write off is a determinant for return on equity, return on assets and profit margin and perhaps most notably, the cost per borrower is a determinant for return on equity and operational self sufficiency. Finally, Observations of the debt/equity variable of the study imply causality for the return on assets and operational self sufficiency as a determinant of respective models.

\section{Conclusion}

Findings of this study contribute towards a better understanding of profitability determinants in the Sri Lankan micro finance institutions. In this study the researcher intends to postulate that, the cost per borrower is a determinant for return on equity and operational self sufficiency. Besides, the operating expense ratio and write off ratios are determinants of return on equity, return on assets and profit margin. Observations of the debt/equity variable of the study imply causality for the return on assets and operational self sufficiency as a determinant of respective models. In a nutshell, the researcher intends to affirm that the Sri Lankan microfinance institutions may attain profitability if those pay emphasis on minimizing cost per borrower, operating expenses, write offs, and gearing.

\section{References}

Abor, J. (2005) "The effect of capital structure on profitability: an empirical analysis of listed firms in Ghana", Journal of Risk Finance, The, Vol. 6 Iss: 5, pp.438 - 445.

Alwis, S. (2008), 'Survey', Central Bank of Sri Lanka, News, July- September 2008, Volume 28, No. 3.

Asian Development Bank, (2000), "Finance for the Poor: Microfinance Development Strategy", Asian Development Bank (ADB).

Barrès, I. (2001). Bosnian Mfis: Performance, And Productivity. Micro Banking Bulletin, (06), 31-34.

Berger, Allen N., and Emilia B. Patti. "Capital Structure and Firm Performance: A New Approach to Testing Agency Theory and an Application to the Banking Industry." 
The Federal Reserve Board . N.p., Oct. 2002. Web. 22 Mar. 2012. <http:// www.federalreserve.gov/pubs/feds/2002/200254/200254pap.pdf $>$.

Charitonenko, S., \& Silva, D. D. (2002). "Commercialization of Microfinance: Sri Lanka, Asian Development Bank, Manila, Philippines, ISBN No. 971-561 480-9, December 2002.

Christen, R.P., McDonald, J., (1998), "The Microbanking Bulletin: Vol. II", The Economics Institute, Boulder.

DCS, (2011), Department of Censes and Statistics- Sri Lanka, May 2011, 'Poverty Indicators', Household Income and Expenditure Survey- 2009/10, Ministry of Finance and Planning, Volume 01 lssue 02,

Diamond, D. W. (1984). Financial intermediation and delegated monitoring. Review of economic studies, Retrieved from www.faculty.chicagobooth.edu/ douglas.diamond/research/fidm small.pdf

Donohoe, N. P. O., Mariz, F. R. D., Littlefield, E., Reille, X., \& Kneiding, C. (2009). Shedding Light on Microfinance Equity Valuation: Past and Present. Occasional papers, Retrieved from http://www.cgap.org/p/site/c/template.rc/1.9.9021 /

Donohoe, Nicholas P O., Frederic Rozeira D. Mariz, Elizabeth Littlefield, Xavier Reille, and Christoph Kneiding. "Shedding Light on Microfinance Equity Valuation: Past and Present." CGAP. N.p., Feb. 2009. Web. 22 Mar. $2012 .<$ http:// www.cgap.org/gm/document-1.9.9021/OP14.pdf $>$.

Elser, L., Hannig, A., \& Winsiwski, S. (1999). Comparative Analysis of Savings Mobilization Strategies. Retrieved from www.pdf.usaid.gov/pdf_docs/ PNACJ088.pdf

Espallier, Bert D., Isabelle Guérin, and Roy Mersland. Gender bias in microfinance. N.p.: n.p., 2009. 2-10. Working Paper, Rural Micro Finance and Employment. Ser. 04. www.rume-microfinance.org. Web. 22 Mar. 2012 . <www.rume-ruralmicrofinance.org/IMG/pdf_WP8.pdf $>$.

Gerschick , J. (2000). Maximizing Efficiency: The Path to Enhanced Outreach and Sustainability. The MicroBanking Bulletin, 12(06), Retrieved from http:// resources.centerforfinancialinclusion.org/publications/Maximizing_117.asp

GTZ ProMis. (2009). Microfinance Industry Report. Colombo: GTZ.

Gujarati D.N., (2008), Basic Econometrics, International Edition, McGraw Hill. 
Hermes, Niels, Robert Lensink, and Aljar Meesters. "Outreach and Efficiency of Microfinance Institutions." Social Science Research Network . N.p., 1 June 2008. SSRN. Web. 22 Mar. 2012. <http://papers.ssrn.com/sol3/ papers.cfm?abstract_id $=1143925>$.

Hulme, D., \& Mosley, P. (1996). Finance against poverty. (Vol. 02, pp. 86-90). London: Taylor and Francis e-library. DOI: www.books.google.com

Kelegama, S. (2001, February). Poverty situation and policy in Sri Lanka. Paper presented at Asia and pacific forum on poverty.

Kereta, B. B. (2007, November). Outreach and financial performance analysis of microfinance institutions in ethiopia.

Maisch, Felipe P., Álvaro T. Sori, and Glenn D. Westley. "How Should Microfinance Institutions Best Fund Themselves?." . N.p., Nov. 2006. Web. 22 Mar. 201 2. <http:/ /www.rrojasdatabank.info/iadbremit/howshould.pdf>.

Meyer, R. L. (2002). Track record of financial . ADB Institute, Research Paper Series, (49), 1-35. Retrieved from http://www.adbi.org/files/ 2002.12.rp049.track.record.pdf

Modigliani, Franco, and Merton H. Miller. "The Cost of Capital, Corporate Finance and the Theory of Investment." mendeley. N.p., 1958. Web. 22 Mar. 201 2. <http:/ /www.mendeley.com/research/cost-capital-corporate-finance-theory-investment$1 />$.

Morduch, Jonathan, Robert Cull, and Asli D. Kunt. Financial Performance and Outreach: A Global Analysis of Leading Microbanks. N.p.: n.p., 2006. 2-25. The World Bank. Web. 22 Mar. 2012. <http://elibrary.worldbank.org/content/ workingpaper/10.1596/1813-9450-3827>.

Muriu, Peter. "Microfinance Profitability: Does financing choice matter?." . N.p., May 2011 . Web. 22 Mar. 2012. <http://www.rug.nl/gsg/Research/Conferences/ EUmicrofinconf2011/Papers/1 new.3C.Muriu.pdf $>$.

Nagarajan, G., 2000, "Productivity Drivers and Trends", The MicroBanking Bulletin, April 2001, Vol. 6, pp. 44-49.; Case Study on BASIX, India and BURO-Tangail, Bangladesh, The MicroBanking Bulletin, Vol. 5, September 2000. www.themix.org Pandey, I. M. (2007). Financial management. (09 ed., pp. 1-10). New Delhi: VIKAS Publishing House. 
Parameshwar," D., Aggarwal,, N., Zanchi, R., \& Shankar, S. S. (2010). Indian MFIs: Growth for Old and New Institutions Alike. The MicroBanking Bulletin (MBB), (20), $1-7$.

Rhyne, Elisabeth, and Maria Otero. (1999). "Financial services for microenterprises: Principles and institutions."http://www.sciencedirect.com. N.p., 5 Mar. 1992. Web. 22 Mar. 2012. < http://www.sciencedirect.com/science/article/pii/ $0305750 \times 9290014 M>$.

Safiuddin, S. K. (2011). Is micro finance a profit maximising industry or a social business - some evidences from recent literature survey. Indian Journal of Commerce \& Management Studies, II(02), 139-142.

Sanderatne, N. (2003). "Leading Issues in Microfinance". Workshop Report: Sarvodaya Economic Enterprise Development Services (GTE) Ltd. Hotel Coral Gardenes, Hikkaduwa, Sri Lanka 2003.

Schmidt, R. H., \& Zeitinger, C. P. (1996). Prospects, problems and potential of creditgranting ngos. Journal of International Development, 08(02), 241-258. Retrieved from http://onlinelibrary.wiley.com/doi/10.1002/(SICI)10991328(199603)8:2<241::AID-JID369>3.0.CO;2-R/abstract

Stauffenberg, D. V., Jansson, T., Kenyon, N., Cruz, M., \& Badiola, B. (2003). Performance indicators for microfinance institutions: Technical guide. (03 ed., pp. 1-15). Washington, D. C.: Inter-American Development Bank. Retrieved from http:// www.scribd.com/doc/57225187/Technical-Guide-3rd-Edition-English

TheMix. (2007, December). 2006 Annual MFI Benchmarks. Retrieved from http:// www.themix.org/publications/mix-microfinance-world/2007/12/2006-annualmfi-benchmarks

Tucker, M., \& Miles, G. (2004). Financial performance of micro?nance institutions: a comparison to performance of regional commercial banks by geographic regions. Journal of Micro?nance,06 (01), 41-54. Retrieved from www.marriottschool.byu.edu/esrreview/articles/article 106.pdf

Ugur, Z. (2006). Commercial banks and microfinance.CUREJ - COLLEGE UNDERGRADUATE RESEARCH ELECTRONIC JOURNAL, Retrieved from http:// repository.upenn.edu/curei/35/ 
Woller. ,Gary, Dunford,, Christopher, , \& Woodworth, W. (1999). Where to microfinance?. International Journal of Economic Development, 01(01), 29-64. Retrieved from www.microfinance.com/English/Papers/ Where_to_Microfinance.pdf

Woolcock, M. J. V. (1999). Learning from failures in microfinance: What unsuccessful cases tell us about how group-based programs work. American Journal of Economics and Sociology, 58(01), 17-42. Retrieved from http://www.jstor.org/

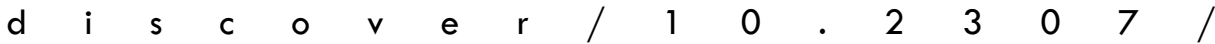
3487873 ?vid $=3738456 \&$ uid $=2129 \&$ vid $=2 \&$ vid $=70 \&$ vid $=4 \&$ sid $=47698850999017$ 